\title{
Humour advertising: A review and a bibliometrics citation analysis
}

\author{
Hafizah Omar Zaki ${ }^{1,2}$, Yusniza Kamarulzaman ${ }^{1 *}$, Mozard Mohtar ${ }^{1}$ \\ ${ }^{1}$ Faculty of Business and Accountancy, University of Malaya \\ ${ }^{2}$ Faculty of Economics and Management, Universiti Kebangsaan Malaysia \\ Correspondence: Yusniza Kamarulzaman (email: yusniza@um.edu.my)
}

Received: 01 March 2020; Accepted: 15 May 2020; Published: 30 May 2020

\begin{abstract}
The purpose of this paper is to present review and analysis of citations by journals, papers and authors, co-occurrences of keyword and sub-keywords, and the co-authorship between authors, institutions as well as countries in the field of humour advertising. The number of journal publications in humour advertising has increased and expanded over the years in the field of marketing, communication and business research, but are less being discussed in relation to its citation's analysis. Therefore, the study has been conducted using a review and a bibliometrics analysis approach. A total of 2300 articles for the study has been extracted from the Web of Science database and reviewed using the PRISMA (Preferred Reporting Items for Systematic Review and Meta-analysed). However, only 1500 were screened and selected for use for the citation analysis. This study contributes in a sense that it provides future researchers with knowledge and information about the worldwide citation's linkages, and networking between authors, institutions, and research interest in the field of humour advertising. This study also provides insights for researchers to engage in developing novel research ideas that may contribute to expanding the engagement of marketing of humour advertising worldwide.
\end{abstract}

Keywords: bibliometrics, humour advertising, marketing research, PRISMA, web of science

\section{Introduction}

As early as the $2^{\text {nd }}$ century B.C, humour became the topic for research in neurosciences where humour mechanism is said to be present in the processing of information in the brain (Martin, 2010). In late $16^{\text {th }}$ century B.C, the studies of humour expanded into the field of psychology and human behaviour (Sher, Foon, Fishman \& Brown, 1976). By the late $19^{\text {th }}$ century, researchers in almost all fields of studies agreed that humour is a mechanism that elicits expressions in the form of laughter and behavioural outcome (Simpson \& Weiner, 1989). This expression of laughter is due to exposure to stimuli or events that contain humorous elements or messages (Wickberg, 1998). Since then, humour has often been used in various television comedies, talk shows and advertising of products and services (Martin, 2010). Humour is evidenced to prompt laughter, persuade and develop positive emotional link with varying levels of products advertised (Eisend, 2009). Humour has also been 
evidently used in diverse marketing scenarios, different product range and various mediums of advertising (Weinberger \& Gulas, 2019). The current status of scholarly research about review of humour advertising and its citation works are still scarce especially in Asia. How the scholarly research shapes the humour advertising field is also an issue that needs great attention in this study. Therefore, to address the issues, the study will use a systematic review and a bibliometric analysis to analyse scholarly academic work on humour advertising. The study hence highlighted four main research questions that will address literatures on humour advertising which include:

1. What are the most prominent journals, papers and authors citations in the field of humour advertising?

2. What are the most co-occurrences of keywords and sub-keywords in the humour advertising?

3. What is the total link strength of the co-authorship between authors, and institutions and countries?

To answer the above-mentioned research questions, this study will conduct the citation analysis through a bibliometric analysis using the VOSviewer bibliometric software. All the articles for the analysis have been taken from the Web of Science (WOS). The result is expected that over the years, the publications in humour advertising to have increased not just in the field of marketing, but also in communication and business research. This study is significant as it provides future researchers knowledge and information about the worldwide networking between authors, institutions and research interest. This study also benefits researchers to engage in novel research ideas in the field of marketing and humour advertising. Finally, this paper can be a useful referencing material for researchers and advertising companies to engage in co-authorship, and for journal editorial boards to keep track of authors' growth and potentials.

\section{Literature review}

A bibliometrics analysis is used to analyse citation, co-citations, co-authorship and other related citations indicators. Bibliometrics is therefore defined as an indicator and a tool used to analyse citation related works (Zupic \& Cater, 2015). Similarly, bibliometrics is also a quantitative analysis of research materials such as topics, samples and methods (Merigo \& Yang, 2017). Bibliometrics studies have been conducted by researches in various fields and expertise (Keramatfar \& Amikhani, 2019; Mulet-Forteza, Genovart-Balaguer, MauleonMendez \& Merigo, 2018; Noorhidawati, Aspura, Zahila \& Abrizah; 2017; Zupic \& Cater, 2015). Over the years, bibliometrics studies expanded into social sciences research such as accounting (Zhong, Geng, Liu, Gao \& Chen, 2016; Merigo \& Yang, 2017), management (Danvila-del-Valle, Estévez-Mendoza \& Lara, 2019; Podsakoff, MacKenzie, Podsakoff \& Bachrach, 2008), economics (Baltagi, 2007; Coupe, 2003), business and communication (Chen, Wang, Tang \& Hao, 2019; Salimi, Tavasoli, Gilani, Jouyandeh \& Sadjadi, 2019), entrepreneurship (Hota, Subramanian \& Narayanamurthy, 2019; Vallaster, Kraus, Lindahl \& Nielsen, 2019), strategic management (Ferreira, Santos, de Almeida \& Reis, 2014; Vogel \& Guttel, 2013) and in broader marketing research (Fetscherin \& Heinrich, 2015; Kim \& McMillan, 2008; Samiee \& Chabowski, 2012) has also been increasingly engaged in bibliometric citations research publications.

In a more specific field of marketing and advertising itself, several bibliometric studies have also been conducted (Barry, 1990; Fetscherin \& Heinrich, 2015; Kim \& 
McMillan, 2008; Leung, Sun \& Bai, 2017; Muncy, 1991; Pasadeos, 1985; Wang \& Hu, 2011). Pasadeos (1985) is among the earliest researchers to work on bibliometric study in advertising and his study highlights detailed analysis of journal citations patterns and their rankings through journals and conference proceedings in advertising and marketing communication. The author also discovered that in the analyses ranging from year 1981 until 1983, Journal of Marketing Research, Journal of Advertising Research and Journal of Advertising were among the most-cited journals with an increased in impact-factor.

On a different view to advertising, Kim and MacMillan (2008) conducted bibliometric study with regards to the Internet advertising and found that Journal of Advertising, Journal of Advertising Research, Journal of Current Issues and Advertising Research and Journal of Interactive Advertising have the most influential cited works in the field of advertising and Internet advertising, and have the most co-citation networks in most of the citations related to Internet advertising. The authors also revealed that the most cited keywords in the Internet advertising are Internet effectiveness, attitude toward internet and traditional vs. Internet advertising medium.

Other papers that have conducted citation analysis in advertising also found that advertising research works are most cited in the Journal of Advertising and Journal of Advertising Research (Muncy, 1991; Gopal \& Tripathi, 2006). Similarly, Wang and Hu (2011) examined keywords related to endorsers in advertisement and uncovered that from 1990 to 2009, there were 39 articles containing endorsers in advertising. Among the articles, the most cited work came from the Journal of Advertising, Journal of Advertising Research and Psychology and Marketing as well as Journal of Consumer Psychology. The author also found that the co-citation for endorsers advertising was represented in 39 citing articles in the period of 20 years.

In essence, albeit the fact that the studies on citation analysis have been conducted in the field of marketing and advertising related research, there are still limited number of studies on bibliometric analysis in area that involves humour in advertising. Moreover, information on the analysis of journal citations, co-citations, co-occurrences and coauthorship with institutions and countries in the field of humour advertising is still novel and scarce. Nevertheless, humour has been referred to a peripheral cue that possesses mechanisms to draw attention, especially in marketing a brand through advertising (Eisend, 2009; Speck, 1991). Therefore, the purpose of this paper is to present analysis of paper citations and analysis of other related citation indexes in the field of marketing of humour advertising.

\section{Method and study area}

The bibliometrics analysis in this study extracted articles' journals from the Web of Science (WOS). WOS is considered as one of the most influential databases with quality research articles. It contains more than 15,000 journals with additional 50 million available articles (Merigo, Mas-Tur, Roig-Tierno \& Ribeiro-Soriano, 2015). The articles on humour advertising have been extracted from WOS using the PRISMA (Preferred Reporting Items for Systematic Review and Meta-analysed) review process which includes three main phases; (1) identification, (2) screening and (3) inclusion and exclusion criteria. The review process was conducted in July 2019 following all three phases. In the first phase, the study conducted a literature search using the Web of Science (WOS) database with keyword searched in the advance search tab TS=(("Humor*" OR "Humour*" OR "Humorous*" OR "Funny*" OR "Funniness*" OR "Comedy*" OR "Hilarious*” OR "Joke*" OR "Pun*" OR "Amusement*" OR “Wittiness*”) AND ("Advertising*”)). This keyword searching produced 2300 articles. 
In the second phase, the 2300 articles were then screened according to several criteria such as (1) document type, (2) language, (3) time line, (4) indexes and (5) categories. This was followed by the third phase of inclusion and exclusion criteria of the screened articles. All the information gathered in these phases functions as a source for bibliometrics analysis in humour advertising. Table 1 depicted the screening, inclusion and exclusion criteria of the articles. In essence, to conduct the bibliometrics analysis, the study choses research articles that are published in English Language and indexed in the Social Science Citation Index (SSCI). The study only includes humour advertising that is published in the Business category as its articles are mostly indexed under the SSCI and main advertising journals are all placed in the business category. Since work on humour advertising is still on the rise, the study includes articles since the first humour advertising papers published in 1986 until 2019. The result from the screening, inclusion and exclusion process finally generated a total of 1500 articles related to humour advertising that are to be used for the bibliometrics analysis.

Table 1. Article extraction from WOS with inclusion and exclusion criteria

\begin{tabular}{lll}
\hline \multicolumn{1}{c}{ Criterion } & \multicolumn{1}{c}{ Inclusion } & \multicolumn{1}{c}{ Exclusion } \\
\hline Document type & $\begin{array}{l}\text { Indexed Journal (research } \\
\text { articles) }\end{array}$ & $\begin{array}{l}\text { Non-indexed journals, Systematic review journals, } \\
\text { chapter in book, conference proceeding }\end{array}$ \\
\hline Language & English & Non-English \\
\hline Time line & $1986-2019$ & Does not exclude any years \\
\hline Indexes & Social Science Citation Index & Science Citation Indexed Expanded \\
\hline Categories & Business & Non-Business \\
\hline
\end{tabular}

The bibliometrics analysis in this study uses the VOSviewer software introduced by Van Eck and Waltman (2010). The software helps in mapping the citations, co-citations, coauthorships and other co-occurrences of the scientific works extracted from WOS (Kovacs, Van Looy, \& Cassiman, 2015; Su \& Lee, 2010). Likewise, the study analyses citations by author, sources (journal), countries, co-citation linkages as well as the co-authorship between institutions and countries in the field of humour advertising. Journals included in the analysis are Journal of Advertising, Journal of Advertising Research, Advances in Consumer Research, European Journal of Marketing, International Journal of Advertising, International Journal of Market Research, Journal of Business Research, Journal of Consumer Psychology, Journal of Consumer Research, Journal of Marketing, Journal of Retailing and Consumer Services, Marketing Science, Psychology and Marketing and Journal of Marketing Research. The above-mentioned journals have been used in this study for bibliometric analysis because most of the research works relates to marketing of humour in advertising.

\section{Results and discussion}

\section{Most cited journals}

This section classified the most cited journals and papers in the field of humour advertising. From the 1500 articles selected for this bibliometrics, we have identified more than 20 journals that publish work on humour advertising. However, the study only selects 14 journals that recorded the highest citations over the two and five-year impact factor as presented in table 2. Journal of Advertising has the highest number of citations of 1577 with impact factor 2.88 in year 2 and impact factor 3.846 in year 5. Similarly, Journal of Consumer research, Journal of Marketing, Journal of Advertising Research, International Journal of Advertising, Psychology and Marketing and Marketing Science are also among the 
journals with highest number of citations. Nevertheless, high cited journals may not represent a high impact factor. This is because a journal with low total citations may have a much higher impact factor than journals with high total citations. Take for instance, Journal of Marketing has a total citation of only 289, but the impact factor for 2-year (7.338) and 5-year (9.592) is much higher than that of other journals with high total citations. Moreover, the hindex refers to the citation threshold in a given dataset (Ellegaard \& Wallin, 2015). Journal of advertising for example has a h-index of 85 , which implies that only 85 papers out of a given set of total papers were cited at least 85 times. In essence, we can conclude that amongst the listed journals, although Journal of Marketing had a low total citation, it has a much higher impact factor and a higher h-index of 208 that would better present a good citation count.

Table 2. Most cited journals on humour advertising and their impact factors

\begin{tabular}{|c|c|c|c|c|c|}
\hline & Sources & $\mathbf{D}$ & $\mathbf{C}$ & $\begin{array}{c}\text { IF } \\
2 \text { years }\end{array}$ & $\begin{array}{c}\text { IF } \\
5 \text { years }\end{array}$ \\
\hline 1 & Journal of Advertising & 34 & 1577 & 2.887 & 3.846 \\
\hline 2 & Journal of Advertising Research & 18 & 261 & 2.328 & 2.709 \\
\hline 3 & Advances in Consumer Research & 4 & 47 & 3.535 & 6.022 \\
\hline 4 & European Journal of Marketing & 3 & 14 & 1.497 & 2.545 \\
\hline 5 & International Journal of Advertising & 18 & 154 & 2.494 & 2.475 \\
\hline 6 & International Journal of Market Research & 2 & 23 & 0.91 & 1.457 \\
\hline 7 & Journal of Business Research & 3 & 43 & 2.509 & 3.689 \\
\hline 8 & Psychology and Marketing & 9 & 159 & 2.023 & 2.631 \\
\hline 9 & Marketing Science & 4 & 182 & 2.794 & 3.918 \\
\hline 10 & Journal of Retailing and Consumer Services & 2 & 2 & 2.919 & No data \\
\hline 11 & Journal of Marketing & 4 & 462 & 7.338 & 9.592 \\
\hline 12 & Journal of Consumer Research & 6 & 738 & 3.535 & 6.022 \\
\hline 13 & Journal of Consumer Psychology & 2 & 44 & 2.809 & 4.427 \\
\hline 14 & Journal of Marketing Research & 1 & 119 & 3.854 & 5.678 \\
\hline
\end{tabular}

*Note: Data retrieved from WOS in July 2019 (C=Citations; D=Documents; IF=Impact Factor)

Most cited journals are also reflected through the total link strength of the journals. An overview of the citation links can be seen in figure 1 of the VOSviewer network visualization. The figure illustrates that Journal of Advertising, Journal of Advertising Research, and International Journal of Advertising with the thickest line has the highest number of citations as well as highest link strength compared to the other 14 listed journals.

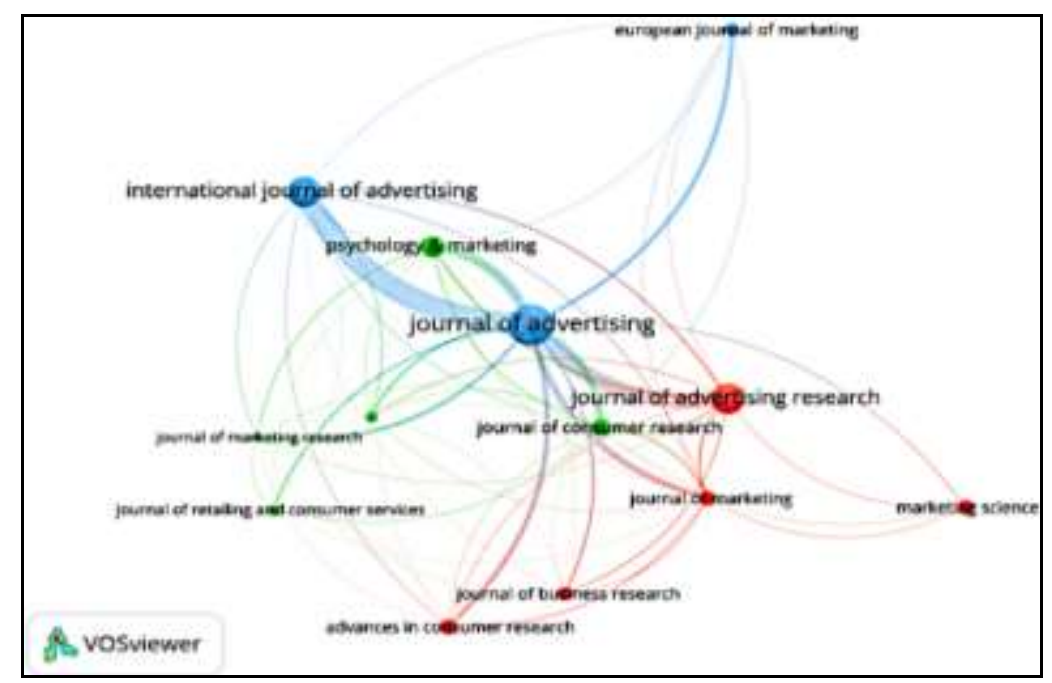

Figure 1. Most cited Journals in the field of humour advertising 


\section{Most cited papers}

With regard to the most cited papers, this study identified top 20 papers that are being cited the most. Table 3 showed the top 20 most cited papers in the field of humour advertising. The highest cited paper is by McQuarrie and Mick in 1996 and 1999 in the Journal of Consumer Research with total citation of 234. Other papers in late 90's and early 2000 that received more than 100 citations are papers written by Pollay and Mittal (1993), De Pelsmacker, Geuens and Anckaert (2002), Weinberger and Gulas (1992), Sternthal and Craig (1973), Alden, Hoyer and Lee (1993), Chattopadhyay and Basu (1990), Lee and Mason (1999), Zhang (1996), Stern (1995), and finally, Alden, Mukherjee and Hoyer (2000). On the other hand, papers with least citations are written by authors from mid-2000 such as Wilbur (2008) with 93 total citations. Such comparison may not be significant or fair because latest or any new publication year will take longer time to get huge number of citations as compared to longstanding publications.

Moreover, the table also indicated the number of self-citations received by most cited papers in the field of humour advertising. From the 20 papers listed, the highest self-citation is on paper by Rossiter and Thornton (2004) published in Psychology and Marketing journal with 11 self-citations. Although it is understood that the more authors a paper has, the higher the probability for the paper to be self-cited. However, the number of self-citations for papers listed in table 3 overall is lower than $20 \%$ or even lesser. This amount of self-citations is therefore still considered low and acceptable according to the Thomson-Reuters self-citation threshold. The lowest self-citation is on papers written by McQuarrie and Mick (1999), Zhang (1996), Tonkar and Munch (2001), Duncan and Nelson (1985), and Lee and Mason (1999) to name a few.

Table 3. Top 20 most cited papers on humour advertising

\begin{tabular}{|c|c|c|c|c|c|c|}
\hline & TC & SC & Title & Author/S & Year & Journal \\
\hline 1 & 234 & 4 & Figures of Rhetoric in Advertising Language & $\begin{array}{l}\text { McQuarrie, EF; } \\
\text { Mick, DG }\end{array}$ & 1996 & $\begin{array}{l}\text { Journal of } \\
\text { Consumer } \\
\text { Research }\end{array}$ \\
\hline 2 & 225 & 1 & $\begin{array}{l}\text { Visual Rhetoric in Advertising: Text-interpretive, } \\
\text { Experimental, and Reader-response Analyses }\end{array}$ & $\begin{array}{l}\text { McQuarrie, EF; } \\
\text { Mick, DG }\end{array}$ & 1999 & $\begin{array}{l}\text { Journal of } \\
\text { Consumer } \\
\text { Research }\end{array}$ \\
\hline 3 & 197 & 3 & $\begin{array}{l}\text { Here's the Beef - Factors, Determinants, and } \\
\text { Segments in Consumer Criticism of Advertising }\end{array}$ & $\begin{array}{l}\text { Pollay, RW; } \\
\text { Mittal, B }\end{array}$ & 1993 & $\begin{array}{l}\text { Journal of } \\
\text { Marketing }\end{array}$ \\
\hline 4 & 151 & 2 & $\begin{array}{l}\text { Media Context and Advertising Effectiveness: The } \\
\text { Role of Context Appreciation and Context/ad } \\
\text { Similarity }\end{array}$ & $\begin{array}{l}\text { De Pelsmacker, } \\
\text { P; Geuens, M; } \\
\text { Anckaert, P }\end{array}$ & 2002 & $\begin{array}{l}\text { Journal of } \\
\text { Advertising }\end{array}$ \\
\hline 5 & 150 & 4 & The Impact of Humor in Advertising - A Review & $\begin{array}{l}\text { Weinberger, MG; } \\
\text { Gulas, CS }\end{array}$ & 1992 & $\begin{array}{l}\text { Journal of } \\
\text { Advertising }\end{array}$ \\
\hline 6 & 130 & 4 & Humor in Advertising & $\begin{array}{l}\text { Sternthal, B; } \\
\text { Craig, CS }\end{array}$ & 1973 & $\begin{array}{l}\text { Journal of } \\
\text { Marketing }\end{array}$ \\
\hline 7 & 122 & 2 & $\begin{array}{l}\text { Identifying Global and Culture-Specific } \\
\text { Dimensions of Humor in Advertising - A } \\
\text { Multinational Analysis }\end{array}$ & $\begin{array}{l}\text { Alden, DL; } \\
\text { Hoyer, WD; Lee, } \\
\text { C }\end{array}$ & 1993 & $\begin{array}{l}\text { Journal of } \\
\text { Marketing }\end{array}$ \\
\hline 8 & 119 & 4 & $\begin{array}{l}\text { Humor in Advertising - The Moderating Role of } \\
\text { Prior Brand Evaluation }\end{array}$ & $\begin{array}{l}\text { Chattopadhyay, } \\
\text { A; Basu, K }\end{array}$ & 1990 & $\begin{array}{l}\text { Journal of } \\
\text { Marketing } \\
\text { Research } \\
\end{array}$ \\
\hline 9 & 101 & 2 & $\begin{array}{l}\text { Responses to Information Incongruency in } \\
\text { Advertising: The Role of Expectancy, Relevancy, } \\
\text { and Humor }\end{array}$ & $\begin{array}{l}\text { Lee, YH; Mason, } \\
\text { C }\end{array}$ & 1999 & $\begin{array}{l}\text { Journal of } \\
\text { Consumer } \\
\text { Research }\end{array}$ \\
\hline 10 & 101 & 1 & $\begin{array}{l}\text { Responses to Humorous Advertising: The } \\
\text { Moderating Effect of Need for Cognition }\end{array}$ & Zhang, Y & 1996 & $\begin{array}{l}\text { Journal of } \\
\text { Advertising }\end{array}$ \\
\hline
\end{tabular}




\begin{tabular}{|c|c|c|c|c|c|c|}
\hline 11 & 101 & 2 & $\begin{array}{l}\text { Consumer Myths - Fryes Taxonomy and The } \\
\text { Structural-Analysis of Consumption Text }\end{array}$ & Stern, BB & 1995 & $\begin{array}{l}\text { Journal of } \\
\text { Consumer } \\
\text { Research }\end{array}$ \\
\hline 12 & 100 & 2 & $\begin{array}{l}\text { The Effects of Incongruity, Surprise and Positive } \\
\text { Moderators Oil Perceived Humor in Television } \\
\text { Advertising }\end{array}$ & $\begin{array}{l}\text { Alden, DL; } \\
\text { Mukherjee, A; } \\
\text { Hoyer, WD }\end{array}$ & 2000 & $\begin{array}{l}\text { Journal of } \\
\text { Advertising }\end{array}$ \\
\hline 13 & 93 & 3 & $\begin{array}{l}\text { A two-sided, Empirical Model of Television } \\
\text { Advertising and Viewing Markets }\end{array}$ & Wilbur, KC & 2008 & $\begin{array}{l}\text { Marketing } \\
\text { Science }\end{array}$ \\
\hline 14 & 91 & 2 & $\begin{array}{l}\text { A content Analysis of Guilt Appeals in Popular } \\
\text { Magazine Advertisements }\end{array}$ & $\begin{array}{l}\text { Huhmann, BA; } \\
\text { Brotherton, TP }\end{array}$ & 1997 & $\begin{array}{l}\text { Journal of } \\
\text { Advertising }\end{array}$ \\
\hline 15 & 88 & 4 & $\begin{array}{l}\text { A Comparison of Print Advertisements from The } \\
\text { United-States and France }\end{array}$ & $\begin{array}{l}\text { Biswas, A; Olsen, } \\
\text { JE; Carlet, V }\end{array}$ & 1992 & $\begin{array}{l}\text { Journal of } \\
\text { Advertising }\end{array}$ \\
\hline 16 & 73 & 3 & $\begin{array}{l}\text { Assessing the Use and Impact of Humor on } \\
\text { Advertising Effectiveness: A contingency } \\
\text { Approach }\end{array}$ & $\begin{array}{l}\text { Spotts, HE; } \\
\text { Weinberger, MG; } \\
\text { Parsons, AL }\end{array}$ & 1997 & $\begin{array}{l}\text { Journal of } \\
\text { Advertising }\end{array}$ \\
\hline 17 & 71 & 3 & $\begin{array}{l}\text { When does Humor Enhance or Inhibit AD } \\
\text { Responses? The Moderating Role of The Need for } \\
\text { Humor }\end{array}$ & $\begin{array}{l}\text { Cline, TW; } \\
\text { Altsech, MB; } \\
\text { Kellaris, JJ }\end{array}$ & 2003 & $\begin{array}{l}\text { Journal of } \\
\text { Advertising }\end{array}$ \\
\hline 18 & 70 & 2 & $\begin{array}{l}\text { Effects of Humor in A Radio Advertising } \\
\text { Experiment }\end{array}$ & $\begin{array}{l}\text { Duncan, CP; } \\
\text { Nelson, JE }\end{array}$ & 1985 & $\begin{array}{l}\text { Journal of } \\
\text { Advertising }\end{array}$ \\
\hline 19 & 63 & 1 & $\begin{array}{l}\text { Consumer Responses to Tropes in Print } \\
\text { Advertising }\end{array}$ & $\begin{array}{l}\text { Toncar, M; } \\
\text { Munch, J }\end{array}$ & 2001 & $\begin{array}{l}\text { Journal of } \\
\text { Advertising }\end{array}$ \\
\hline 20 & 49 & 11 & $\begin{array}{l}\text { Fear-Pattern Analysis Supports the Fear-drive } \\
\text { Model for Anti-speeding Road-safety TV ads }\end{array}$ & $\begin{array}{l}\text { Rossiter, JR; } \\
\text { Thornton, J }\end{array}$ & 2004 & $\begin{array}{l}\text { Psychology } \\
\text { \& Marketing }\end{array}$ \\
\hline
\end{tabular}

*Note: TC=total citations, SC=self-citation. Source: Data retrieved from WOS in July 2019

\section{Most cited authors}

This section of study presented top 20 most cited authors in the field of humour advertising research. Table 4 shows that author number 1 until 9 are among the top authors with highest number of total citations of more than 1000 , a citation per year of more than 50 , and a hindex of more than 20. Although Hoyer WD has the highest total citations of 7219, his total publications of 154 is still lower than that of Laroche with 464 publications. Highest number of papers may not represent real productivity of authors (Merigo et al., 2015), thus, productivity of authors with highest total citations and high citations per year are considered as having real productivity (Merigo et al., 2015; Tur-Porcar, Mas-Tur, Merigo, Roig-Tierno $\&$ Watt, 2018). Finally, every author in Table 4 have a h-index that are more than 2 . For instance, Hoyer WD has a H-index of 38 which indicates that the author's productivity and citation impact are relatively high; and that 38 out of 154 total paper are at least being cited. On the contrary, Zhang Y among others have the lowest total citations of only 58, citations per year of 5 , and a h-index of 7 .

Table 4. Top 20 most cited authors on humour advertising

\begin{tabular}{clccccc}
\hline No. & \multicolumn{1}{c}{ Author } & TP & TC & C/P & SC & H-I \\
\hline 1 & Hoyer WD & 154 & 7219 & 171.88 & 69 & 38 \\
\hline 2 & Laroche M & 464 & 6416 & 164.51 & 125 & 41 \\
\hline 3 & Cline TW & 78 & 4736 & 110.14 & 51 & 37 \\
\hline 4 & Zinkhan GM & 153 & 4003 & 111.19 & 62 & 36 \\
\hline 5 & Yoon HJ & 202 & 3146 & 104.87 & 60 & 31 \\
\hline 6 & Alden DL & 48 & 2356 & 87.26 & 23 & 20 \\
\hline 7 & De Pelsmacker P & 103 & 2002 & 64.58 & 60 & 22 \\
\hline 8 & Geuens M & 57 & 1276 & 70.89 & 27 & 18 \\
\hline 9 & Eisend M & 56 & 1059 & 26.48 & 30 & 18 \\
\hline 10 & Kellaris JJ & 42 & 913 & 30.43 & 19 & 19 \\
\hline 11 & Gelb BD & 77 & 852 & 17.75 & 6 & 13 \\
\hline 12 & Weinberger MG & 27 & 661 & 16.95 & 12 & 12 \\
\hline
\end{tabular}




\begin{tabular}{llccccc}
\hline 13 & Gulas CS & 14 & 546 & 20.22 & 6 & 8 \\
\hline 14 & Mukherjee A & 14 & 467 & 25.94 & 6 & 7 \\
\hline 15 & Huhmann BA & 16 & 300 & 14.29 & 4 & 7 \\
\hline 16 & Galloway G & 8 & 287 & 15.94 & 5 & 7 \\
\hline 17 & Costley C & 17 & 244 & 7.39 & 1 & 8 \\
\hline 18 & Zhang Y & 5 & 58 & 5.27 & 1 & 2 \\
\hline 19 & Boutsouki C & 7 & 42 & 5.25 & 2 & 3 \\
\hline 20 & Hatzithomas L & 6 & 30 & 3.75 & 3 & 2 \\
\hline
\end{tabular}

*Note: $\mathrm{TP}=$ total publications, $\mathrm{TC}=$ total citations, $\mathrm{C} / \mathrm{P}=$ citation per year, $\mathrm{SC}=$ self-citation,H-I=H-Index.

Source: Data retrieved from WOS in July 2019

\section{Co-occurrence analysis}

This section of the study explained the co-occurrence of major keywords in the field of humour advertising. The co-occurrence is measured by the main keywords and the line of networks that links the keywords to other sub-keywords in the field being studied (Cancino, Merigo, Coronado, Dessouky, \& Dessouky, 2017; Martinez-Lopez, Merigo, Valenzuela, \& Nicolas, 2018). Figure 2 illustrates the keywords co-occurrence that links to humour. The biggest circle or node which is humour depicted the main relevancy of the keywords under study. In the network linkages, humour is linked with other sub-keywords such as attitudes, emotions, memory, media, effectiveness, advertisements, behaviour, persuasion, involvement, communication and many others. The circle or nodes confirm the linkages or networks related to humour in advertising. The distance between the nodes depicted the distance and strength of the co-occurrence between the main keyword themes with the subkeywords. The closer the distance, the stronger the co-occurrence occurring between keywords; whereas, the farther the distance, the lesser and weaker the co-occurrences are. In this network diagram, advertisements and media seems to be the closest distance, making humour prevalent in advertising research.

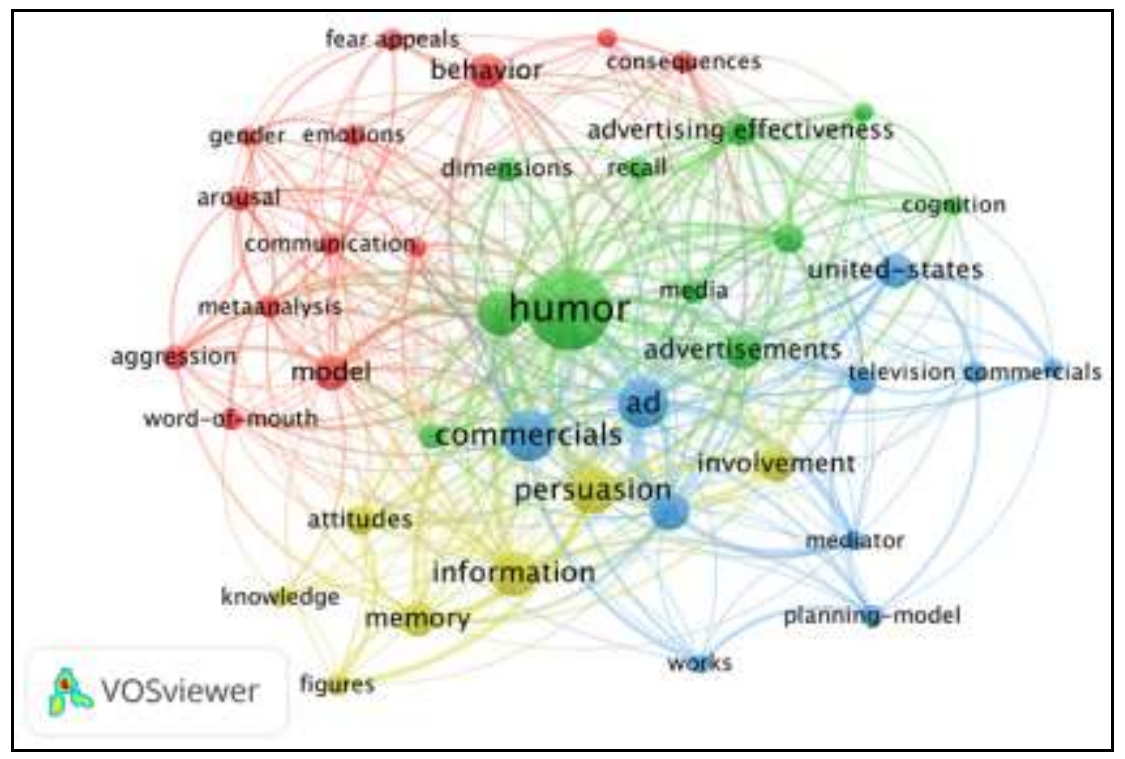

Figure 2. Co-occurrence of keywords and sub-keywords 


\section{Co-authorship between authors}

Co-authorship is also known as a collaborative effort among individual researchers with other researchers, institutions and countries (Ponomariov \& Boardman, 2016). Co-authorship therefore builds relationships and networking among a community of researchers. Figure 3 illustrates the co-authorship link's strength between authors in the humour advertising research. In this networking circle, Eisend and De Pelsmacker illustrated as having the biggest co-authorship links. Eisend $\mathrm{M}$ has a co-authorship networking with Sollwedel, Plagemann, Roessner, Kaemmerer, Dens, De Meulenaer, and De Pelsmacker. On the other hand, De Pelsmacker has a co-authorship relationship with Eisend, De Meulenaer, Dens, Geuens, and Anckaert. The figure also shows that from 2000 to 2010, publications in relation to humour advertising are conducted mostly by the co-authorship between De Pelsmacker, Geuens, and Anckaert. Likewise, from late 2010 to 2015, Eisend, Sollwedel, Plagemann, and De Meulenaer have the highest co-authorship publication works. In late year 2015, Co-author publications in humour advertising have been mostly done between Eisend, Kaemmerer, Roessner, Dens, and De Meulenaer.

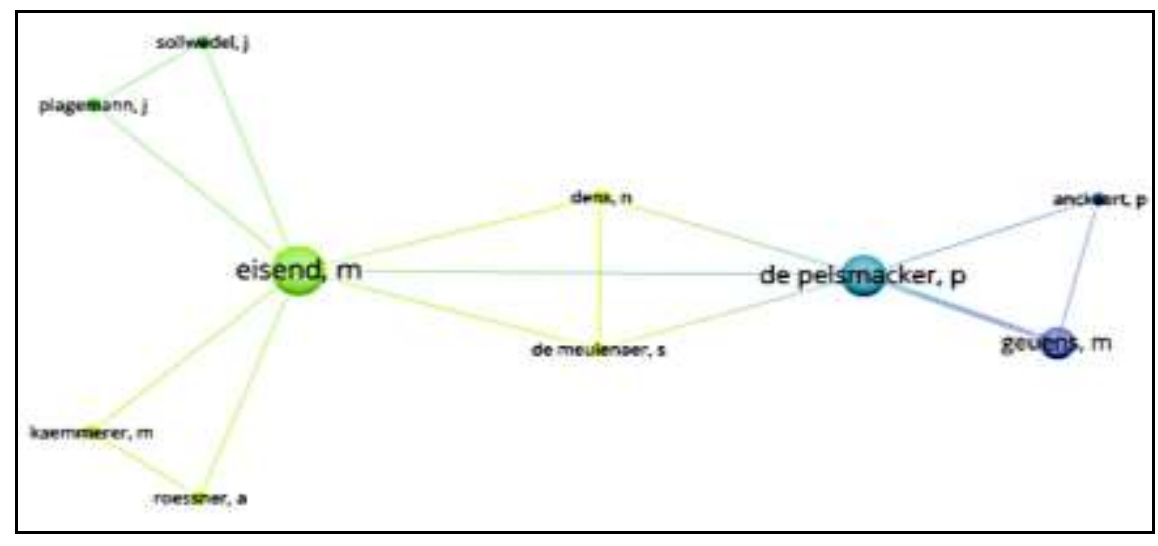

Figure 3. Co-authorship between authors in the field humour advertising

The increased number of researches on humour in advertising has also increased the number of research collaborations between authors. Therefore, Figure 4 illustrated another group of co-authorship between authors, extending that of figure 3. Figure 4 showed that Weinberger, Gulas, and Yoon has the largest networking for co-authorship. In 2013, coauthorship work occurred between Weinberger and Mckeage. In early year of 2014, Weinberger, and Gulas has the most co-author link strength in publishing works on humour advertising. Consistently, in year 2015, Yoon, Swani, and Weinberger are more productive in their co-authorship work in publishing humour advertising papers. In essence, although the field of humour advertising has expanded over the years with increased number of papers published in quality top-tier journals, the number of co-authorships between authors of the same interest is still limited where the linkages of networks between authors are still small and not wide spread unlike any other fields in the marketing research. 


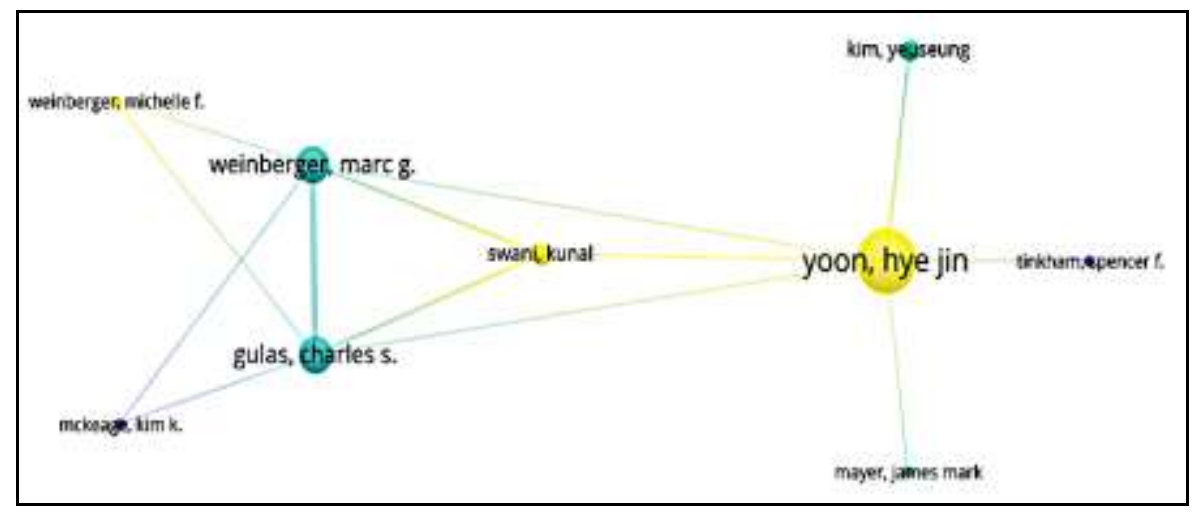

Figure 4. Extended co-authorship between authors in the field humour advertising

\section{Co-authorship between institutions}

Co-authorship between Institutions ensure that there is an active mechanism to drive research work and to build networking professionally (Ponomariov \& Boardman, 2016). Figure 5 exhibits links between Institutions (Universities) working on co-authorship. The figure explains that most of the co-authorship for humour advertising research occurs between Universities in the United States. The Wright State University, University of Massachusetts, and University of Georgia are among the spearheads that link the other Universities to engage in the co-authorship for research in humour advertising. This also indicates that humour advertising is a very well-known topic in the U.S and is synonym to the American Universities research interest. However, this may not be a universal engagement for Universities adopting different research interest and dissimilar research concentrations. Hence, this limitation allows Institutions namely Universities from other parts of the world to contribute to the co-authorship works which may strengthen relationships between Universities worldwide; and may allow extensive exchange of knowledge in humour advertising research.

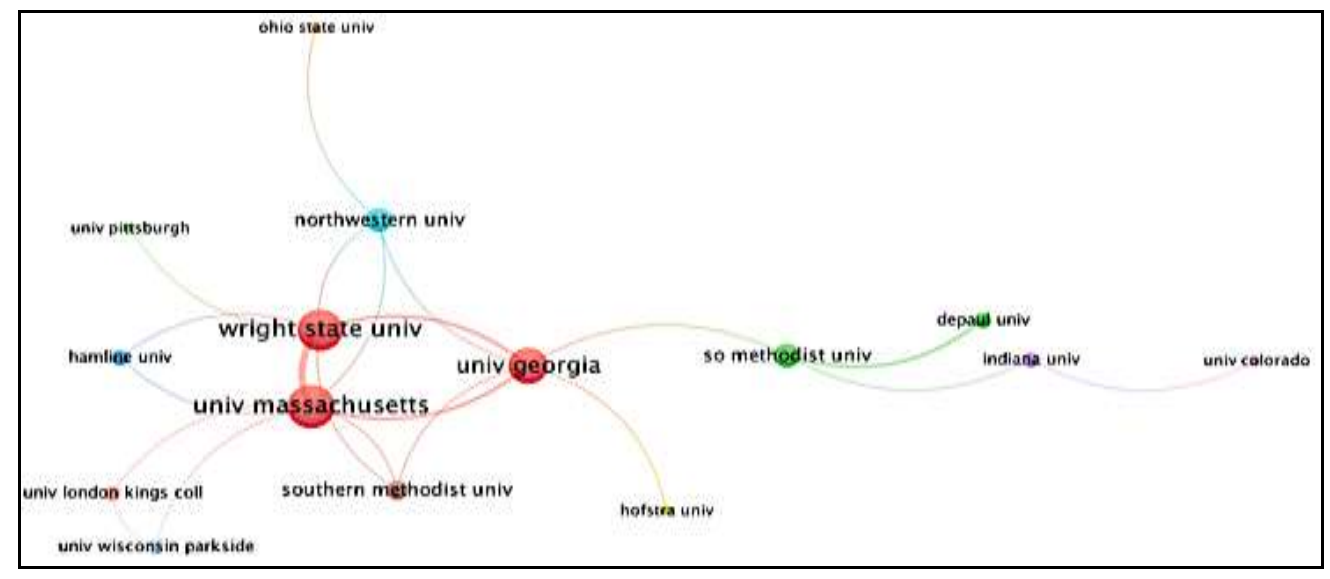

Figure 5. Co-authorship between Institutions/Universities in the field humour advertising

\section{Co-authorship between countries}

Although co-authorship between authors and Universities is limited in that it only occurs among the American scope, the co-authorship between countries around the world is on the rise. Fig.6 illustrates the co-authorship networking between several countries for humour 
advertising research. The figures show that co-authorship of humour advertising research which began in the US has expended to England, China, Australia, Canada, Sweden, Germany and France. Hence, this has evidenced an improvement in cross-countries research engagement on research related to humour in advertising. Essentially, the co-authorship should also be stretched into the Asian and South East Asian Region in order to engage in broader researcher networking effort which may also allow cultural exchange of knowledge and ideas in relation to humour advertising.

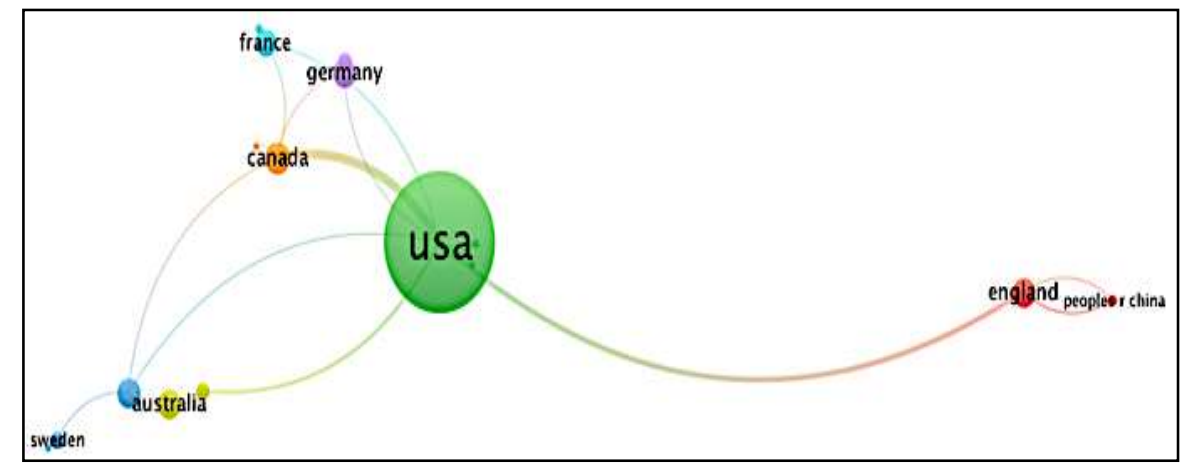

Figure 6. Co-authorship between countries

\section{Conclusion}

This paper delivers the bibliometrics analysis of research works pertaining to humour advertising. In the first stage, the study had conducted the citation analysis for most cited journals, top 20 most cited papers in humour advertising and most cited authors. Firstly, the findings discovered that Journal of Advertising (JOA), Journal of Marketing (JOM) and Journal of Advertising Research (JAR) have the highest number of citations among other journals listed. The most cited papers and authors are indicated as strong and productive when the number of total citations is relatively high. Some of the top 20 papers receive a score of more than 100 total citations. Secondly, co-occurrence of keywords in humour advertising suggesting that words such as attitudes, emotions, memory, advertisements and communications were among the highest number keywords used. Finally, the results for coauthorship assessment between authors, institutions and countries indicated that although coauthorship between countries has shown an expansion of networking, the co-authorship between authors and institutions for research work related to humour advertising is still not universal and occurs only in the USA's networking range. Countries in Asia has yet to collaborate with any institutions within its region or even with institutions in the West. This brings to future opportunity for co-authorship in humour advertising research between countries globally.

Nevertheless, the study has its limitation where this study only considered articles indexed in the social science citation index (SSCI), and only humour advertising articles published under the business category in the WOS. Secondly, the study only uses WOS database as articles retrieval platform without considering other available databases. Despite these limitations, the study delivered a reliable and valid overview of the analysis of most dominant research works in humour advertising that are based on the citation, cooccurrences, and co-authorship analysis. Future studies can extend this study by including other indexes such as the Emerging Sources Citation Index (ESCI) to assist new and inexperienced authors in the field. Future researchers can also expand the use of databases such as SCOPUS, SCImago journal rank, Google Scholar and many others in the article selection process. In essence, this study is significant as it provides future researchers 
knowledge and information of the worldwide citations and citation counts of articles and journals in the field of humour advertising, and marketing in general. The study also supports to build networking between authors, institutions and research interest in the field. Finally, this study benefits young researchers to engage in novel research ideas in the field of humour advertising.

\section{Acknowledgement}

We would like to thank the Ministry of Higher Education, and the Universiti Kebangsaan Malaysia for funding this research through a Postgraduate Study Leave Scheme Fund (SLAB).

\section{References}

Alden, D.L., Mukherjee, A., \& Hoyer, W.D. (2000). The effects of incongruity, surprise and positive moderators on perceived humor in television advertising. Journal of Advertising, 29(2), 1-15.

Alden, D.L., Hoyer, W.D., \& Lee, C. (1993). Identifying global and culture-specific dimensions of humor in advertising: A multinational analysis. Journal of Marketing, 57(2), 64-75.

Barry, T.E. (1990). Publication productivity in the three leading US advertising journals: Inaugural issues through 1988. Journal of Advertising, 19(1), 52-60.

Baltagi, B.H. (2007). Worldwide Econometrics Rankings: 1989-2005. Econometric Theory, 23(5), 952-1012.

Bonilla, C.A., Merigó, J.M., \& Torres-Abad, C. (2015). Economics in Latin America: A bibliometric analysis. Scientometrics, 105(2), 1239-1252.

Cancino, C., Merigó, J.M., Coronado, F., Dessouky, Y., \& Dessouky, M. (2017). Forty years of Computers \& Industrial Engineering: A bibliometric analysis. Computers \& Industrial Engineering, 113, 614-629.

Chen, X., Wang, S., Tang, Y., \& Hao, T. (2019). A bibliometric analysis of event detection in social media. Online Information Review, 43(1), 29-52.

Coupe, T. (2003). Revealed performances: Worldwide rankings of Economists and Economics Departments, 1990-2000. Journal of the European Economic Association, 1(6), 1309-1345.

Chattopadhyay, A., \& Basu, K. (1990). Humor in advertising: The moderating role of prior brand evaluation. Journal of Marketing Research, 27(4), 466-476.

De Pelsmacker, P., Geuens, M., \& Anckaert, P. (2002). Media context and advertising effectiveness: The role of context appreciation and context/ad similarity. Journal of Advertising, 31(2), 49-61.

Danvila-del-Valle, I., Estévez-Mendoza, C., \& Lara, F. J. (2019). Human resources training: A bibliometric analysis. Journal of Business Research, 101, 627-636. DOI : https://doi.org/ 10.1016/j.jbusres.2019.02.026

Duncan, C.P., \& Nelson, J.E. (1985). Effects of humor in a radio advertising experiment. Journal of Advertising, 14(2), 33-64.

Eisend, M. (2009). A meta-analysis of humor in advertising. Journal of the Academy of Marketing Science, 37(2), 191-203.

Ellegaard, O., \& Wallin, J.A. (2015). The bibliometric analysis of scholarly production: How great is the impact? Scientometrics, 105(3), 1809-1831. 
Fetscherin, M., \& Heinrich, D. (2015). Consumer brand relationships research: A bibliometric citation meta-analysis. Journal of Business Research, 68(2), 380-390.

Ferreira, M.P., Santos, J.C., de Almeida, M.I.R., \& Reis, N.R. (2014). Mergers \& acquisitions research: A bibliometric study of top strategy and international business journals, 1980-2010. Journal of Business Research, 67(12), 2550-2558.

Gopal, R.D., \& Tripathi, A.K. (2006). Advertising via wireless networks. International Journal of Mobile Communications, 4(1), 1-16.

Hota, P.K., Subramanian, B., \& Narayanamurthy, G. (2019). Mapping the intellectual structure of social entrepreneurship research: A citation/co-citation analysis. Journal of Business Ethics, 1-26.

Kim, J., \& McMillan, S.J. (2008). Evaluation of internet advertising research: A bibliometric analysis of citations from key sources. Journal of Advertising, 37(1), 99-112.

Keramatfar, A., \& Amirkhani, H. (2019). Bibliometrics of sentiment analysis literature. Journal of Information Science, 45(1), 3-15.

Kovacs, A., Van Looy, B., \& Cassiman, B. (2015). Exploring the scope of open innovation: A bibliometric review of a decade of research. Scientometrics, 104(3), 951-983.

Lee, Y.H., \& Mason, C. (1999). Responses to information incongruency in advertising: The role of expectancy, relevancy, and humor. Journal of Consumer Research, 26(2), 156169.

Leung, X.Y., Sun, J., \& Bai, B. (2017). Bibliometrics of social media research: A co-citation and co-word analysis. International Journal of Hospitality Management, 66, 35-45.

Martin, R.A. (2010). The Psychology of Humor: An Integrative Approach. Academic press.

Martinez-Lopez, F.J., Merigo, J.M., Valenzuela-Fernandez, L., \& Nicolas, C. (2018). Fifty years of The European Journal of Marketing: A bibliometric analysis. European Journal of Marketing, 52(1/2), 439-468.

McQuarrie, E.F., \& Mick, D.G. (1999). Visual rhetoric in advertising: Text-interpretive, experimental, and reader-response analyses. Journal of consumer research, 26(1), 37 54.

Mulet-Forteza, C., Genovart-Balaguer, J., Mauleon-Mendez, E., \& Merigó, J.M. (2018). A bibliometric research in the tourism, leisure and hospitality fields. Journal of Business Research, 101, 819-827.

Muncy, J.A. (1991). The Journal of Advertising: A twenty-year appraisal. Journal of Advertising, 20(4), 1-12.

Merigo, J.M., \& Yang, J.B. (2017). Accounting research: A bibliometric analysis. Australian Accounting Review, 80(27), 71-100.

Merigo, J.M., Mas-Tur, A., Roig-Tierno, N., \& Ribeiro-Soriano, D. (2015). A bibliometric overview of the Journal of Business Research between 1973 and 2014. Journal of Business Research, 68(12), 2645-2653.

Noorhidawati, A., Aspura, M.Y.I., Zahila, M.N., \& Abrizah, A. (2017). Characteristics of Malaysian highly cited papers. Malaysian Journal of Library \& Information Science, 22(2), 85-99.

Pasadeos, Y. (1985). A bibliometric study of advertising citations. Journal of Advertising, 14(4), 52-59.

Ponomariov, B., \& Boardman, C. (2016). What is co-authorship? Scientometrics, 109(3), 1939-1963.

Pollay, R.W., \& Mittal, B. (1993). Here's the beef: Factors, determinants, and segments in consumer criticism of advertising. Journal of marketing, 57(3), 99-114.

Rossiter, J.R., \& Thornton, J. (2004). Fear-pattern analysis supports the fear-drive model for anti-speeding road-safety TV ads. Psychology \& Marketing, 21(11), 945-960. 
Salimi, D., Tavasoli, K., Gilani, E., Jouyandeh, M., \& Sadjadi, S. (2019). The impact of social media on marketing using bibliometrics analysis. International Journal of Data and Network Science, 3(3), 165-184.

Samiee, S., \& Chabowski, B.R. (2012). Knowledge structure in international marketing: A multi-method bibliometric analysis. Journal of the Academy of Marketing Science, 40(2), 364-386.

Sher, N.A., Foon, K.A., Fishman, M.L., \& Brown, T.M. (1976). Demonstration of Macrophage Chemotactic Factors in the aqueous humor during experimental Immunogenic Uveitis in rabbits. Infection and immunity, 13(4), 1110-1116.

Simpson, J., \& Weiner, E.S. (1989). Oxford English Dictionary Online. Oxford: Clarendon Press. Retrieved March 6, 2018.

Small, H. (1973). Co-citation in the scientific literature: A new measure of the relationship between two documents. Journal of the American Society for information Science, 24(4), 265-269.

Stern, B.B. (1995). Consumer myths: Frye's taxonomy and the structural analysis of consumption text. Journal of consumer research, 22(2), 165-185.

Sternthal, B., \& Craig, C.S. (1973). Humor in advertising. Journal of Marketing, 37(4), 1218.

Su, H., \& Lee, P. (2010). Mapping knowledge structure by keyword co-occurrence: A first look at journal papers in Technology Foresight. Scientometrics, 85, 65-79.

Speck, P.S. (1991). The humorous message taxonomy: A framework for the study of humorous ads. Current issues and research in advertising, 13(1-2), 1-44.

Tur-Porcar, A., Mas-Tur, A., Merigó, J.M., Roig-Tierno, N., \& Watt, J. (2018). A bibliometric history of The Journal of Psychology between 1936 and 2015. The Journal of psychology, 152(4), 199-225.

Toncar, M., \& Munch, J. (2001). Consumer responses to tropes in print advertising. Journal of Advertising, 30(1), 55-65.

Vallaster, C., Kraus, S., Lindahl, J.M.M., \& Nielsen, A. (2019). Ethics and entrepreneurship: A bibliometric study and literature review. Journal of Business Research, 99, 226237.

Vogel, R., \& Guttel, W.H. (2013). The dynamic capability view in strategic management: A bibliometric review. International Journal of Management Reviews, 15(4), 426-446.

Wang, C.C., \& Hu, W.C. (2011). Bibliometric analysis of advertising endorser research in marketing. International Proceedings of Economics Development \& Research, 3, 102106.

Wickberg, D. (1998). The senses of humor: Self and laughter in modern America. Cornell University Press.

Wilbur, K.C. (2008). A two-sided, empirical model of television advertising and viewing markets. Marketing science, 27(3), 356-378.

Weinberger, M.G., \& Gulas, C.S. (1992). The Impact of humor in advertising: A review. Journal of advertising, 21(4), 35-59.

Weinberger, M.G., \& Gulas, C.S. (2019). The emergence of a half-century of research on humour in advertising: what have we learned? What do we still need to learn? International Journal of Advertising, 38(7), 911-956.

Yadava, S.M., Patrick, H.S., Ananth, C.V., Rosen, T., \& Brandt, J.S. (2019). Top-cited articles in the journal: A bibliometric analysis. American Journal of Obstetrics and Gynecology, 220(1), 12-25.

Zhang, Y. (1996). Responses to humorous advertising: The moderating effect of need for cognition. Journal of Advertising, 25(1), 15-32. 
Zhang, Y. (1996). The effect of humor in advertising: An individual-difference perspective. Psychology \& Marketing, 13(6), 531-545.

Zupic, I., \& Cater, T. (2015). Bibliometric methods in management and organization. Organizational Research Methods, 18(3), 429-472.

Zhong, S., Geng, Y., Liu, W., Gao, C., \& Chen, W. (2016). A bibliometric review on natural resource accounting during 1995-2014. Journal of Cleaner Production. 139, 122-132. 